\title{
MRAS wt Allele
}

National Cancer Institute

\section{Source}

National Cancer Institute. MRAS wt Allele. NCI Thesaurus. Code C52548.

Human MRAS wild-type allele is located in the vicinity of $3 q 22.3$ and is approximately 58

$\mathrm{kb}$ in length. This allele, which encodes Ras-related protein M-Ras, may play a role in signal transduction for many cellular processes. 